\title{
A Case of Papillary Squamous Cell Carcinoma Which Associated with Inverted Papilloma in Sinonasal Cavity
}

\author{
Pyung Mo Gu ${ }^{1}$, Seong Kook Park ${ }^{1}$, and Soo Jin Jung ${ }^{2}$ \\ ${ }^{1}$ Departments of Otorhinolaryngology-Head and Neck Surgery, ${ }^{2}$ Pathology, College of Medicine, Inje University, \\ Busan Paik Hospital, Busan, Korea
}

비부비강 반전성 유두종과 병발한 유두상 편평 상피세포암 1 예

구평모 ${ }^{1} \cdot$ 박성국 $^{1} \cdot$ 정수진 ${ }^{2}$

인제대학교 의과대학 부산백병원 이비인후-두경부외과학교실, ${ }^{1}$ 병리학교실 ${ }^{2}$

\author{
Received April 29, 2014 \\ Revised July 8, 2014 \\ Accepted July 14, 2014 \\ Address for correspondence \\ Seong Kook Park, MD \\ Department of Otorhinolaryngology- \\ Head and Neck Surgery, \\ College of Medicine, Inje University, \\ Busan Paik Hospital, \\ 75 Bokji-ro, Busanjin-gu, \\ Busan 614-735, Korea \\ Tel $+82-51-890-6379$ \\ Fax +82-51-892-3831 \\ E-mailssinus4@paik.ac.kr
}

According to the classification of World Health Organization, papillary squamous cell carcinoma is a variant of squamous cell carcinoma. This is a malignancy rarely found in the upper aerodigestive tract, especially in the sinonasal tract. We experienced a case, in which a 50-yearold man had papillary squamous cell carcinoma on his right nasal cavity, accompanied with inverted papilloma and fungiform papilloma. They were resected via endoscopic and Caldwell-Luc's approach. After the operation, the patient was treated with radiotherapy for 7 weeks, and has been disease-free for two years. We present the clinical characteristics, pathology, treatment, and prognosis of the tumor with a review of the literature.

Korean J Otorhinolaryngol-Head Neck Surg 2015;58(4):275-8

Key Words Carcinoma, papillary $\cdot$ Nose $\cdot$ Papilloma, inverted $\cdot$ Paranasal sinuses.

\section{서 론}

비부비강에 발생하는 악성종양은 전체 두경부 종양의 $3 \%$ 정도로 비교적 드물며, 특히 비부비강의 악성 편평 상피세포 종(squamous cell carcinoma)은 전체 악성종양의 $1 \%$ 미만, 두경부에서 발생하는 악성종양의 $3 \%$ 정도로 알려져 있다.

2005년 세계보건기구(World Health Organization, WHO) 에서 발표한 비부비강 악성종양의 분류에 따르면 유두상 편 평 상피세포암(papillary squamous cell carcinoma)은 편평 상피세포암의 아형 중에서도 매우 드문 암종으로 유두상 모 양의 성장을 특징으로 하며, 주로 50 70대 남성에서 대부분 후두에 발생하고 그 외 구인두, 비부비동, 구강 등 상부 호흡기 계에 발생하기도 한다. ${ }^{2,3)}$

현재까지 국외에서는 혀, 후두, 구강 및 비부비강을 포함한 상부호흡기계에서 발생한 유두상 편평 상피세포암에 대한 보 고가 있으나, ${ }^{4-7)}$ 국내에서는 편평 상피세포암에 대한 보고는 많
은 반면 유두상 편평 상피세포암에 대해서는 문헌으로 아직 보고된 바가 없다.

이에 저자들은 비폐색을 주소로 내원한 50세 남자 환자에서 우측 비강 반전성 유두종과 병발한 유두상 편평 상피세포암 1 예를 경험하였기에 이를 문헌고찰과 함께 보고하는 바이다.

\section{증 겨}

50 세 남자 환자가 내원 1주 전부터 발생한 우측 코막힘으 로 본원 이비인후과에 방문하였다. 내원시 시행한 이학적 검 사에서 우측 중비갑개와 비중격 사이에 출혈을 동반하는 표 면이 비교적 규칙적인 분홍색의 종괴가 보였으며(Fig. 1) 그 외 고막, 구강, 경부 진찰 및 과거력에 특이 소견은 없었다. 부 비동 전산화단층촬영상 우측 비강내 연부조직 음영이 우측 상악동까지 퍼져있는 소견과 안와벽부위 골파괴 의심되는 소견을 보였으며 안와내 침범, 두개골 기저부 침범 등의 소견 
은 보이지 않았다(Fig. 2). 수술 전 외래에서 중비갑개와 비 중격 사이 종괴부분에서 생검을 시행하였으며 조직병리 결 과 $\mathrm{p} 53$ 종양억제 유전자의 변이가 동반된 버섯모양유두종 (fungiform papilloma)임을 확인하였다. 환자는 10년 전부 터 당뇨병을 않아왔고, 술 전 시행한 임상검사에서 이상 소 견은 없었다.

전신마취하 종괴의 완전적출을 위해 Caldwell-Luc's approach 및 비내시경을 동시에 활용하는 수술을 시행하였다. 비내시경상 우측 중비갑개 및 하비갑개와 비중격 사이, 중비도 로, 우측 상악동에 이르는 종괴가 관찰되었으며 우측 윗잇몸

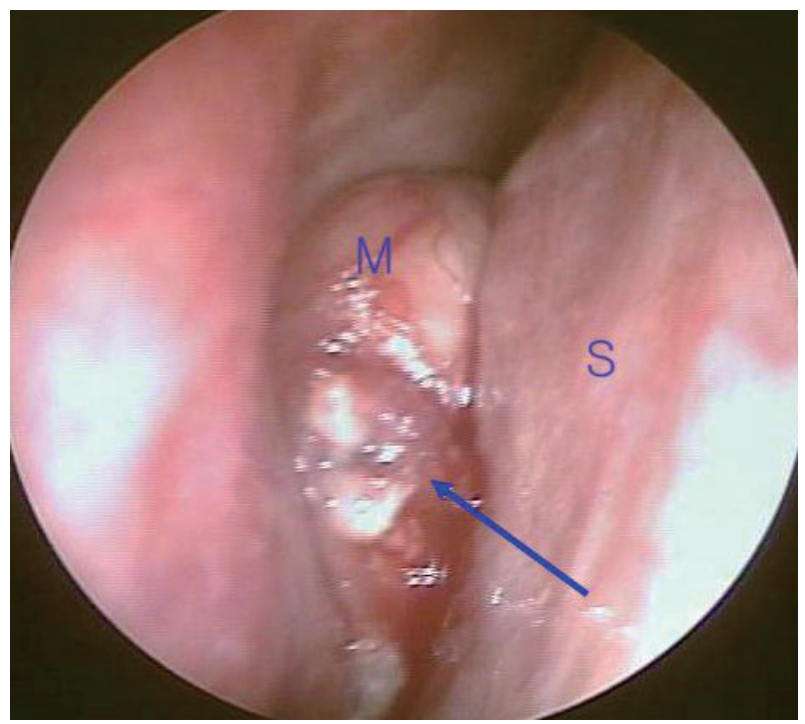

Fig. 1. Endoscopy demonstrates hemorrhagic ovoid mass between Rt. middle turbinate and nasal septum (arrow: mass, S: septum, M: middle turbinate).

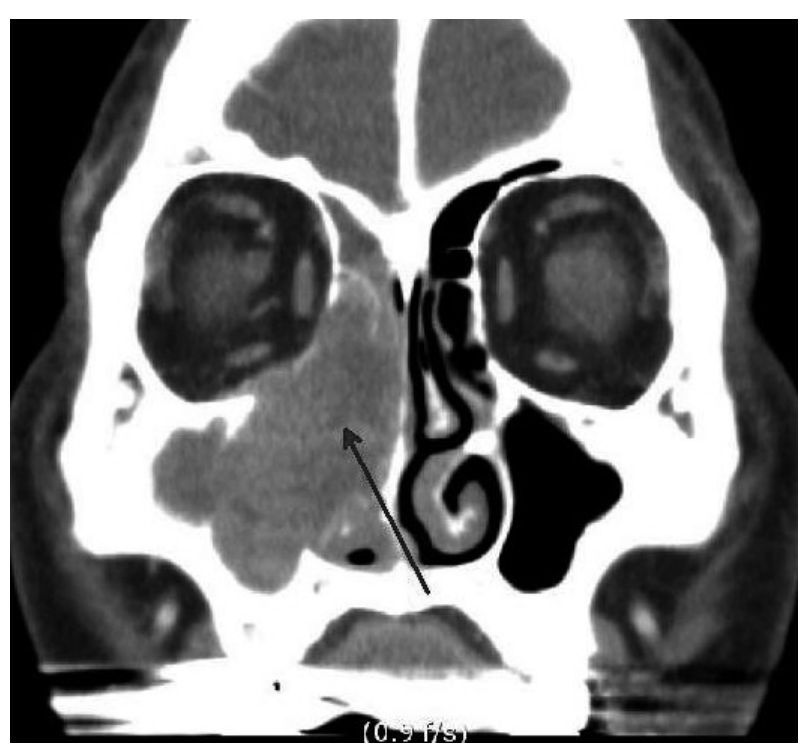

Fig. 2. Paranasal sinus computed tomography scan reveals a soft tissue density at Rt. sinonasal tract with suspicious destructive bone change (arrow).
에 약 $3 \mathrm{~cm}$ 의 절개를 가한 뒤, Freer-Joseph elevator(Storz, Germany)를 이용해 골막을 박리하여 상악동의 전벽을 노출 하였다. Cottle Mallet(Storz, Germany)과 Walter Gouge(Storz, Germany)를 이용하여 상악동의 전벽에 $1 \times 1 \mathrm{~cm}$ 정도의 구멍을 만든 뒤 상악동내 종괴를 최대한 제거하였으며, 비내시경적 접근에서는 Straightshot M4 Microdebrider(Medtronic, USA) 및 Halle Ethmoid Curette(Storz, Germany)을 이용하여 유두종성 병변 및 주변의 점막, 골조직도 충분히 포함하여 모 두 제거하였다. 술 전 시행한 컴퓨터단층촬영상 의심되었던 안 와벽 외에 상악동 외측벽의 결손이 추가로 관찰되었으나 각각 의 결손범위가 적어 주변점막들을 충분히 제거한 뒤 소작술을 시행하였으며, 비강내의 중비도로에 존재하는 종물부분에서 동결절편검사를 시행한 결과 반전성 유두종이 의심되며 종양 세포는 발견되지 않아 Furazine gauze와 Merocel ${ }^{\circledR}$ 을 이용한 비강충전을 시행한 후 수술을 마쳤다.

환자는 수술 후 2 일째 비강 충전물들을 제거하였으며, 수술 후 6일째 비출혈 및 안구증상등의 합병증 없이 퇴원하였다.

수술 후 확인한 최종조직 검사 결과 비강에서 얻은 조직은 반전성 유두종의 조직학적 소견을 보인 반면 부비강에서 얻 은 조직은 유두부분이 융합되어 간질층을 침범하는 소견을 보였다. 또한 편평상피 전층이 다수의 유사분열을 동반하는 미성숙 이형성 세포들로 구성되어 있는 소견을 보여 버섯모 양유두종에서 기원하는 유두상 편평 상피세포암에 합당한 소견을 보였고, 따라서 반전성 유두종과 병발한 유두상 편평 상피세포암으로 최종 진단하였다(Fig. 3). 환자는 술 후 7주 간 $7000 \mathrm{cGy}$ 의 방사선치료를 받았으며, 수술 후 2년째 시행 한 내시경 및 컴퓨터단층촬영에서 재발 소견 없이 현재 외래 추적관찰 중이다.

\section{고 찰}

비부비강의 편평 상피세포암은 WHO Classification상 여 러 아형으로 분류되며 유두상 편평 상피세포암은 이러한 편 평 상피세포암의 분류 중에서도 매우 드문 암종이다.1)

유두상 편평 상피세포암의 발생원인은 아직 분명히 밝혀 진 것이 없으며 인간유두종바이러스(human papilloma virus) 와 관련된 양성 종양이 빈번히 발생하는 후두와 비부비동에 서 발병한다는 점에서 human papilloma virus 감염과의 연 관성이 제시되고 있으나, Jo 등 ${ }^{8}$ 의 연구에서는 $68 \%$ 에서, Cobo 등 ${ }^{9}$ 의 연구에서는 $50 \%$ 에서 human papilloma virus 관련성을 확인할 수 있는 반면 Suarez 등이 의 연구에서는 14 개의 증례 중 5예, Thompson 등 ${ }^{11)}$ 의 연구에서는 41 예 중 단 1 예에서만 그 관련성이 확인되어 인과관계는 아직 명확하지 않은 실정 

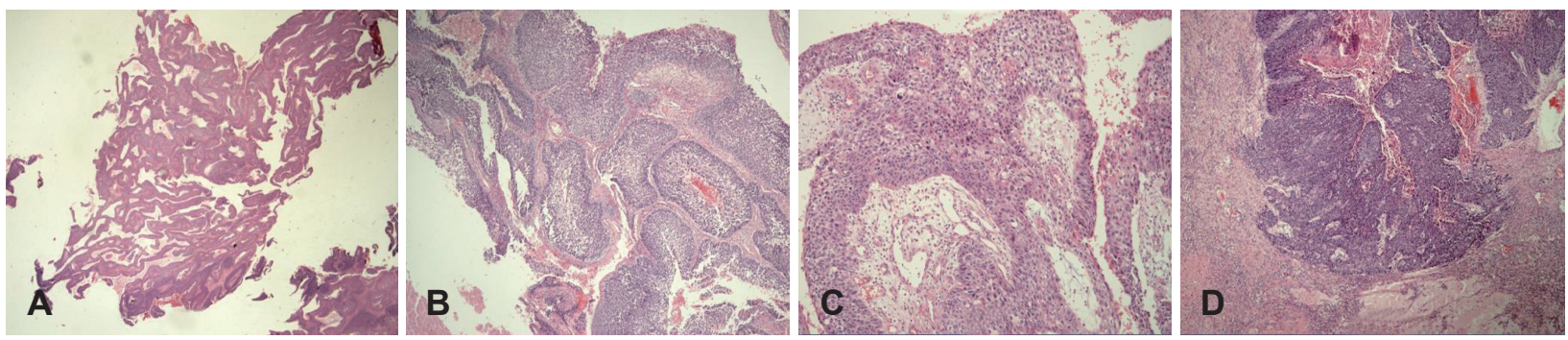

Fig. 3. Biopsed tissue from nasal cavity shows inverted papilloma $(H \& E, \times 10)(A)$. Other fragment of mass reveals papillary squamous cell carcinoma showing dysplastic cells arising in fusiform papilloma (H\&E, $\times 100)(B)$. The epithelium is composed of immature atypical cells with frequent mitosis throughout the entire thickness $(H \& E, \times 200)(C)$. The papillaes are fused and invaded in stroma $(H \& E, \times 100)(D)$.

이나, 최근에는 구인두에 발병하는 유두상 편평 상피세포암 의 경우 구강 혹은 후두에 발병하는 경우보다 human papilloma virus와의 관련성이 높다는 결과가 있다.12) 이외 면역염색학 적으로 유두상 편평 상피세포암에서 p53 protein의 과발현을 보인다는 보고가 있고 ${ }^{13)}$ Suarez 등이의 연구에서 14 예의 유 두상 편평 상피세포암중 11예에서 p53 protein의 과발현이 관찰되었다는 보고가 있으나 관련성이 확실히 입증된 연구결 과는 없어 향후 추가적인 연구가 필요하다고 생각된다.

이러한 유두상 편평 상피세포암은 주로 유두종 같은 양성 병변이 같이 존재하지 않고 단독으로 생기는 경우가 많으나, 본 증례와 같이 전구가 되는 유두종이 존재하는 경우 또는 유 두종발병의 과거력이 있는 경우도 보고되고 있으면) Suarez 등 $^{10)}$ 의 연구에서는 약 $34 \%$ 에서 유두종과의 연관성을 보였다.

비부비강에 발생한 유두상 편평 상피세포암의 증상으로는 편평 상피세포암의 아형으로서 흔히 비부비동에 발생하는 반전성 유두종과 동반된 편평 상피세포암과 같이 비폐색, 비 루, 후각감퇴, 비출혈 등의 증상이 있을 수 있다고 생각되며 ${ }^{15}$ 본 증례에서는 비폐색이 주증상이었다.

진단은 임상소견, 비강 내시경소견, 영상학적 검사 및 수술 후 조직검사를 통해 내릴 수 있으며 조직학적으로 유두상 편 평 상피세포암은 다수의 유두상 구조물이 모든 면에 존재하 며 악성 변화가 있는 중층 편평 상피로 덮여있으며 이러한 유두부분에서 상피전층에 걸쳐 다수의 유사분열을 볼 수 있 고, 핵/세포질 비율은 증가 및 핵의 불규칙성을 관찰할 수 있 으며 종양성의 미성숙한 기저양세포(basaloid cell) 혹은 다 형세포로 덮인 얇은 섬유혈관성 중심부를 가지고 있다. 세포 내의 각질화 또는 이상각질화가 있을 수 있으나 표면의 각질 층은 대부분 보이지 않거나 국소적으로 존재하는 것이 특징 이다. 유두상 편평 상피세포암과 감별해야 할 진단으로는 양성 비부비동 유두종과 사마귀모양암종(verrucous carcinoma) 등 이 있으며 ${ }^{13)}$ 양성 유두종은 세포학적 이형성이 관찰되지 않고, 사마귀모양암종은 조직학적으로 실모양으로 자라는 양상이 더 뚜렷한 것으로 감별할 수 있다.

치료는 종양의 완전한 수술적 절제 후 방사선치료가 일반
적이며, 두경부에서의 유두상 편평 상피세포암은 국소재발 률은 비교적 높으나 일반적인 편평 상피세포암에 비해 수술 후 추가적인 방사선 치료를 통하여 더 좋은 예후를 기대할 수 있는 것으로 알려져 있다. ${ }^{23,12,16)}$ 일반적인 두경부 영역에서 유두상 편평 상피세포암의 5년 생존율은 약 $70 \%$ 정도로 알 려져 있고 ${ }^{3)}$ Russell 등ㄹㅇㅢ 연구에서는 두경부 영역에서 비부 비강에서 재발한 경우는 $75 \%$ 였으나 2년, 5 년 생존율은 각각 $90 \%, 72 \%$ 였으며 본 증례에서도 완전한 수술적 절제 후 방사 선치료를 병행하였고 2년 동안 특별한 합병증 및 재발이 없 어 비교적 양호한 예후가 예상되는 바이다. 또한 임상의들은 본 증례에서처럼 술 전 외래에서 확인한 조직검사 및 수술 중 시행한 동결절편조직검사상 반전성 유두종으로 의심하였으나, 최종 조직검사 결과는 유두상 편평 상피세포암으로 진단되는 경우도 있다는 것을 숙지하고 수술 후 반드시 외래에서 permanent biopsy 결과를 확인하는 것이 중요하다고 생각된다.

\section{REFERENCES}

1) Pilch BZ, Bouquot J, Thompson LDR. Squamous cell carcinoma. In: Barnes L, Eveson JW, Reichart P, Sidransky D, editors. Pathology and genetics of head and neck tumours. World Health Organization classification of tumours. 9th ed. Lyon: IARC Press;2005. p.15-7.

2) Russell JO, Hoschar AP, Scharpf J. Papillary squamous cell carcinoma of the head and neck: a clinicopathologic series. Am J Otolaryngol 2011;32(6):557-63.

3) Thompson LDR. Squamous cell carcinoma variants of the head and neck. Curr Diagn Pathol 2003;9(6):384-96.

4) Marques YM, Chicaro CF, Tosta M, Kowalski LP, dos Santos Pinto D Jr. Papillary squamous cell carcinoma of the tongue. Otolaryngol Head Neck Surg 2009;141(2):298-9.

5) Ereño C, López JI, Sánchez JM, Bilbao FJ. Papillary squamous cell carcinoma of the larynx. J Laryngol Otol 2001;115(2):164-6.

6) Terada T. Papillary squamous cell carcinoma of the oral cavity with acantholytic and pseudovascular features. Int J Clin Exp Pathol 2011; 4(8):794-6.

7) Ferrer MJ, Estellés E, Villanueva A, López R. Papillary squamous cell carcinoma of the oropharynx. Eur Arch Otorhinolaryngol 2003; 260(8):444-5.

8) Jo VY, Mills SE, Stoler MH, Stelow EB. Papillary squamous cell carcinoma of the head and neck: frequent association with human papillomavirus infection and invasive carcinoma. Am J Surg Pathol 2009;33(11):1720-4.

9) Cobo F, Talavera P, Concha A. Review article: relationship of human papillomavirus with papillary squamous cell carcinoma of 
the upper aerodigestive tract: a review. Int J Surg Pathol 2008;16(2): 127-36.

10) Suarez PA, Adler-Storthz K, Luna MA, El-Naggar AK, AbdulKarim FW, Batsakis JG. Papillary squamous cell carcinomas of the upper aerodigestive tract: a clinicopathologic and molecular study. Head Neck 2000;22(4):360-8.

11) Thompson LD, Wenig BM, Heffner DK, Gnepp DR. Exophytic and papillary squamous cell carcinomas of the larynx: A clinicopathologic series of 104 cases. Otolaryngol Head Neck Surg 1999;120(5):718-24.

12) Mehrad M, Carpenter DH, Chernock RD, Wang H, Ma XJ, Luo Y, et al. Papillary squamous cell carcinoma of the head and neck: clinicopathologic and molecular features with special reference to human papillomavirus. Am J Surg Pathol 2013;37(9):1349-56.

13) Stelow EB, Mills SE. Squamous cell carcinoma variants of the upper aerodigestive tract. Am J Clin Pathol 2005;124 Suppl:S96-109.

14) Wenig BM. Squamous cell carcinoma of the upper aerodigestive tract: precursors and problematic variants. Mod Pathol 2002;15(3): 229-54.

15) Min IK, Koo BS, Park CH, Kim AY, Park SW, Rha KS. Inverted papilloma of the nose and paranasal sinuses: an analysis of 102 cases. Korean J Otolaryngol-Head Neck Surg 2003;46(8):659-64.

16) Yang CH, Huang CC, Ko MT, Wei YC, Hwang CF. Human papillomavirus infection and papillary squamous cell carcinoma in the head and neck region. Tumour Biol 2013;34(1):301-7. 